\title{
Hyper IgE syndrome associated with novel DOCK8 heterozygous mutation: a case report
}

\author{
${ }^{1}$ SI «Institute of Pediatrics, Obstetrics and Gynecology named after academician O. Lukyanova \\ of the National Academy of Medical Sciences of Ukraine», Kyiv \\ ${ }^{2}$ Shupyk National Medical Academy for Postgraduate Education, Kyiv, Ukraine
}

Modern Pediatrics.Ukraine.2020.1(105):63-65; doi 10.15574/SP.2020.105.63

For citation: Osypchuk DV, Hilfanova AM. (2020). Hyper IgE syndrome associated with novel DOCK8 heterozygous mutation: a case report. Modern Pediatrics. Ukraine. 1(105): 63-65. doi 10.15574/SP.2020.105.63

Dedicator of cytokinesis 8 (DOCK8) deficiency is an autosomal recessive combined immunodeficiency within the spectrum of hyper-lgE syndromes. The clinical case. Here we report a patient with a novel heterozygous mutation in DOCK8 gene associated with a clinical presentation of hyper-lgE syndrome (HIES).

A case report. The patient presented with severe congenital atopic dermatitis, allergic rhinitis and bronchial asthma which was developed during the 3rd year of life. Also, the patient suffered from recurrent otitis and lymphadenopathy of the inguinal lymph nodes. The immune evaluation showed normal lymphocytes subpopulation and increased serum IgE - 32.131 IU/L. Genetic sequencing revealed a heterozygous defect c.5266A>T (p.lle1756Phe) in the D0CK8 gene. Therapy with omalizumab was started and a significant improvement of skin syndrome was achieved.

Conclusions. Our data and therapeutic approach may be clinically useful as the diagnostic and treatment approach for severe atopic dermatitis that does not fit the full criteria for previously reported hyper-lgE syndromes.

The research was carried out in accordance with the principles of the Helsinki Declaration. The study protocol was approved by the Local Ethics Committee of all participating institution. The informed consent of the child's parents was obtained from the studies.

No conflict of interest was declared by the authors.

Key words: hyper-IgE syndrome, DOCK8, severe atopic dermatitis, omalizumab.

\section{Гіпер-IgE синдром, пов'язаний із новою гетерозиготною мутацією DOCK8: клінічний випадок \\ Д.В. Осипчук', А.М. Гільфанова ${ }^{2}$}

'ДУ «нститут педіатрії, акушерства і гінекології імені академіка О.М. Лук'янової Національної академії медичних наук України», м. Київ

${ }^{2}$ Національна медична академія післядипломної освіти імені П.Л. Шупика, м. Київ, Україна

DOCK8 (dedicator of cytokinesis 8) десіцит є аутосомно-рецесивним комбінованим імунодесріцитом у спектрі гіпер-IgE синдромів. У даній статті повідомляється про випадок нової гетерозиготної мутації гена DOCK8, пов'язаної з клінічним проявом гіпер-IgE синдрому (HIES), у дитини.

Клінічний випадок. Хвора мала важкий вроджений атопічний дерматит, алергічний риніт та бронхіальну астму, яка розвинулася на третьому році життя. Також пацієнтка страждала на рецидивний отит та лімфаденопатію пахових лімфатичних вузлів. Оцінка стану імунної системи показала нормальні субпопуляції лімфроцитів та підвищення IgE у сироватці крові - 32,131 М0/л. Генетичне секвенування виявило гетерозиготний дефект c.5266A $>$ T (p.lle1756Phe) в гені D0CK8. Розпочато терапію омалізумабом та досягнуто значного поліпшення шкірного синдрому.

Висновки. Описаний у статті діагностичний та лікувальний підхід до важкого атопічного дерматиту, який не відповідає повним критеріям для синдромів гіпер-IgE, у дитини може бути корисним для клініциста.

Дослідження виконані відповідно до принципів Гельсінської Декларації. Протокол дослідження ухвалений Локальним етичним комітетом всіх зазначених у роботі установ. На проведення досліджень було отримано поінформовану згоду батьків дитини.

Автори заявляють про відсутність конфрлікту інтересів.

Ключові слова: синдром гіпер-IgE, DOCK8, важкий атопічний дерматит, омалізумаб.

\section{Гипер-IgE синдром, связанный с новой гетерозиготной мутацией DOCK8: клинический случай} Д.В. Осипчук', А.М. Гильфанова ${ }^{2}$

ГГУ «Институт педиатрии, акушерства и гинекологии имени академика Е.М. Лукьяновой Национальной академии медицинских наук Украины», г. Киев ${ }^{2}$ Национальная медицинская академия последипломного образования имени П.Л. Шупика, г. Киев, Украина

DOCK8 (dedicator of cytokinesis 8) дефицит является аутосомно-рецессивным комбинированным иммунодесрицитом в спектре гипер-IgE синдромов. В данной статье сообщается о случае новой гетерозиготной мутации гена DOCK8, связанной с клиническим проявлением гипер-IgE синдрома (НIES), у ребенка.

Клинический случай. Больная имела тяжелый врожденный атопический дерматит, аллергический ринит и бронхиальную астму, которая развилась на третьем году жизни. Также пациентка страдала рецидивирующим отитом и лимфаденопатией паховых лимфатических узлов. Оценка состояния иммунной системы показала нормальные субпопуляции лимфоцитов и повышение lgE в сыворотке крови - 32,131 МЕ/л. Генетическое секвенирование выявило гетерозиготный дефект с.5266A>T (p.ІІе1756Phe) в гене D0CK8. Начата терапия омализумабом и достигнуто значительного улучшения кожного синдрома

Выводы. Описанный в статье диагностический и лечебный подход к тяжелому атопическому дерматиту, который не отвечает полным критериям для синдромов гипер-IgE, у ребенка может быть полезен для клинициста.

Исследование было выполнено в соответствии с принципами Хельсинкской Декларации. Протокол исследования был одобрен Локальным этическим комитетом всех участвующих учреждений. На проведение исследований было получено информированное согласие родителей ребенка.

Авторы заявляют об отсутствии конфоликта интересов.

Ключевые слова: синдром гипер-IgE, DOCK8, тяжелый атопический дерматит, омализумаб. 


\section{Introduction}

Hyperimmunoglobulin E syndromes (HIESs) are rare diseases among primary immunodeficiency (PID) disorders, characterized by elevated immunoglobulin (Ig) E levels, eosinophilia and recurrent Staphylococcal infections. Bi-allelic loss-of-function mutations in the guanine-nucleotide exchange factor dedicator of cytokinesis 8 (DOCK8) cause autosomal recessive (AR)-HIES. [3]

Although heterozygous carriers of mutant DOCK8 alleles appear clinically normal, there are several reports of heterozygous DOCK8 mutated gene carriers with various clinical manifestations. [1,2]

In this study we describe the case of a patient with a heterozygous mutation in the DOCK8 gene, with extremely elevated IgE levels and severe congenital atopic dermatitis, asthma and recurrent sinopulmonary infections.

\section{Case presentation}

The patient is a 5-year-old female presented with severe chronic atopic dermatitis, dysplastic ears and hypermobility of the joints, shortened right leg (by $1 \mathrm{~cm}$ ), high palate and recurrent infections. The patient suffered from dermatitis from birth, from the age of 3 weeks; the rash has spread and intensified, accompanied by marked itching. The eczema was of recurrent nature, accompanied by widespread skin lesions (with the most severe lesions located in the joints), peeling, lichenification, itching, numerous deep excoriations and fissures, as well as superinfection with pyogenic bacteria and candida.

The exacerbations are expressed as vulvitis, enlargement and pain in the inguinal lymph nodes. From age 3.5, the false joints syndrome was noted expressed as joint pain, limitation of physical activity and morning stiffness without synovitis. In addition to the continued use of emollients and topical steroids, systemic steroids were required for control. A strict elimination diet did not improve the child's condition.

The first episode of bronchial obstruction occurred at age 2 against the background of influenza and shortness of breath episodes; consumption subsequently occurred against the background of viral respiratory infection or provoked by cold air. From age 2, the patient suffered from constant nasal congestions; she was diagnosed with allergic rhinitis and bronchial asthma. The rhinitis was year-round in character and significantly impaired the quality of life. The basic therapy of asthma and AR with topical steroids was started at age 2 years 11 months (3 mild exa- cerbations of asthma at age 3-4 were noted). The allergic history is also complicated by specific sensitization to buckwheat (manifested by Quincke's swelling), to egg whites and egg yolks, as well as to numerous foods (identified during provocative tests). The mother was allergic to bee stings and herbal medications.

The infectious syndrome is represented by recurrent skin-mucous bacterial-fungal infections (vulvitis, conjunctivitis, nasopharyngitis, adenoiditis), a left buttock abscess at age 3.5 , as well as by recurrent purulent otitis and rhinosinusitis and recurrent lip sore. In particular, at age 4 an episode of bilateral purulent otitis caused by the multidrug-resistant Pseudomonas aeruginosa was observed.

The patient was found to have normal or increased IgG levels - 14.2-17.86 (5.4-14.2 g/L), slightly increased IgA levels $-2.97(0.5-2.2 \mathrm{~g} / \mathrm{L})$, variable IgM levels - 0.15-0.96-1.87 (0.4-2.0 g/L), and increased serum IgE level (32.131 IU/L) and normal Isohemagglutinins $\beta$ level (1:32). The immunology profile showed variable eosonophilia and normal lymphocytes subsets. Deficiencies of vitamin D (25-OH-D <3.0 ng / mL) and iron were detected.

The patient has negative laboratory markers for celiac disease and autoimmunity, and was seropositive to HSV 1, EBV and seronegative to HIV, Toxocara.

No hereditary disorders of the amino acid' or acylcarnitines metabolism were detected. No pathological changes in the cerebral arteries were detected on MRI scans.

Genetic analysis revealed normal SPINK5, STAT3, TYK2 genes. Genetic sequencing revealed a heterozygous defect c.5266A $>$ T (p.Ile1756Phe), a variant of uncertain significance in the DOCK8 gene.

Therapy with omalizumab (150 mg / once every 2 weeks) was started. The first efficacy evaluation (after 4 injections) revealed an improved general condition of the child, as well as an amelioration of skin manifestations. The inguinal lymph nodes were decreased in size and no exacerbation of bronchial asthma and allergic rhinitis was observed.

The second and third effectiveness assessment (after 12 and 24 injections) revealed residual skin lesions in the lower extremities. No exacerbations of bronchial asthma (with no therapy administered for 9 months) or allergic rhinitis (with no baseline therapy administered for 10 months) were noted. Short-term administration of low systemic glucocorticosteroid doses (prednisone $10 \mathrm{mg}$ for 1 day, $5 \mathrm{mg}$ for $2-3$ more days) is required several times a month. 
The research was carried out in accordance with the principles of the Helsinki Declaration. The study protocol was approved by the Local Ethics Committee (LEC) of all participating institution. The informed consent of the child's parents was obtained from the studies.

\section{Discussion}

Dedicator of cytokinesis 8 (DOCK8) deficiency is an autosomal recessive combined immunodeficiency within the spectrum of hyper-IgE syndromes: eczematous dermatitis, recurrent sinopulmonary infections, Staphylococcus aureus skin abscesses, elevations in serum IgE levels, and, sometimes, mucocutaneous candidiasis. [1]

In this case report, the patient had a heterozygous defect c.5266A $>\mathrm{T}$ (p.Ile1756Phe), a variant of uncertain significance in the DOCK8 gene, and had extremely elevated IgE levels, a history of atopy, recurrent sinopulmonary and skin infections. Commonly, patients with DOCK8 mutations have a combined immunodeficiency with low $\mathrm{T}$ cell and B cell numbers, low serum IgM levels and variable $\operatorname{IgG}$ antibody responses. [4] An immunological investigation revealed that our patient, despite recurrent sinopulmonary and skin infections, displayed no signs of combined immu- nodeficiency (e.g., lymphopenia) or low levels of serum immunoglobulins. Interestingly, the patient has hypermobility of joints (that is more usual for autosomal dominant hyper-IgE), as well as aplastic ears and high palate.

\section{Conclusion}

The c.5266A $>\mathrm{T}$ variant is a previously unreported mutation that is likely responsible for the findings in this patient. Although heterozygous carriers of mutant DOCK8 alleles appear clinically normal, our and previous reports suggest that extensive longitudinal studies on their phenotypes are needed to reveal if heterozygosity for DOCK8 is associated with health risks. Our data and therapeutic approach may be clinically useful as the diagnostic and treatment approach for severe atopic dermatitis that does not fit the full criteria for previously reported hyper-IgE syndromes.

\section{Funding sources}

This research did not receive any specific grant from funding agencies in the public, commercial, or not-for-profit sectors.

No conflict of interest was declared by the authors.

\section{REFERENCES/JITEPATУPA}

1. Dinetz S, Wray BB. (2016). Case Report of a Previously Unreported Type of DOCK8 Deficiency. J Allergy Clin Immunol. 137: 393.

2. Hansra D, Cioffi-Lavina M, Granada H, Mclntyre B et al. (2017). Rare Case of Adult Onset DOCK8 Mutated Hyper Ige Syndrome. Blood. 130: 4825.
3. Su HC, Jing H, Angelus P, Freeman AF. (2019). Insights into immunity from clinical and basic science studies of DOCK8 immunodeficiency syndrome. Immunol. Rev. 287: 9-19.

4. Zhang Q, Davis JC, Lamborn IT, Freeman AF et al. (2009). Combined Immunodeficiency Associated with DOCK8 Mutations. N Engl J Med. 361(21): 2046-2055.

\section{Відомості про авторів:}

Осипчук Дарія Віталіївна - к.б.н., н.с. лабораторії імунології ДУ «ІПАГ імені академіка О.М. Лук'янової НАМН України», лаборант каф. дитячих інфекційних хвороб та дитячої імунології НМАПО імені П.Л. Шупика. Адреса: м. Київ, вул. П. Майбороди, 8; тел. (044) 484-18-71.

Гільфанова Анна Михайлівна - к.мед.н., асистент каф. дитячих інфекційних хвороб та дитячої імунології НМАПО імені П.Л. Шупика.

Адреса: м. Київ, вул. Дорогожицька, 9; тел. (044) 201-32-04.

Стаття надійшла до редакції 23.11.2019 р., прийнята до друку 06.02.2020 p 